\title{
Disc Herniation and Cyst Gas: A Rare Association Causing Radicular Compression
}

\section{Herniação de gás intraespinal: uma associação rara causando compressão radicular}

\author{
Cherkaoui Mandour $^{1} \quad$ Miloudi Gazzaz $^{1}$ Brahim el Mostarchid ${ }^{1}$ \\ ${ }^{1}$ Department of Neurosurgery; Military Hospital Mohammed V, \\ Address for correspondence Cherkaoui Mandour, MD, Department of \\ Rabat, Morocco \\ Neurosurgery, Military Hospital Mohammed V, Rabat 10000, Morocco \\ (e-mail: mandour1978@hotmail.com).
}

Arq Bras Neurocir 2017;36:133-135.

\begin{abstract}
Introduction Intraspinal gas is a common clinical finding, but an epidural gas pseudocyst in association with lateral disc herniation compressing a nerve root is an exceptional observation.

Case Report A 49-year-old man was admitted to our department presenting with sciatica. The neurological examination demonstrated moderate lumbar pain without neurological deficit. A lumbosacral computed tomography showed the presence of degenerated disc herniation and epidural gas collection.

Keywords

- disc herniation

- gas pseudocyst

- sciatica

\section{Resumo}

\section{Palavras-Chave}

- hérnia discal

- pseudocisto de gás

- ciática

Discussion The pathological association between the cyst and the hernia is probably due to the migration of gas pumped from the intervertebral space through a breaking point or lower in the annulus fibrosis, involving its contiguity with the herniated disc. Conclusion An association between a disc herniation and a gas pseudocyst can be a cause of sciatica.

Introdução O gás intraespinal é um achado clínico comum, mas um pseudocisto epidural de gás associado a herniação discal lateral comprimindo uma raiz nervosa é uma observação excepcional.

Relato de caso Um homem de 49 anos de idade foi admitido em nosso departamento apresentando sintomas de ciática. O exame neurológico demonstrou dor lombar moderada sem déficit neurológico. A tomografia computadorizada lombossacral mostrou presença de hérnia discal degenerada e coleta epidural de gás.

Discussão A associação patológica entre o cisto e a hérnia é provavelmente devida à migração do gás bombeado do espaço intervertebral através de um ponto de ruptura ou menor na fibrose do anel, envolvendo a sua contiguidade com o disco herniado. Conclusão Uma associação entre uma hérnia de disco e um pseudocisto de gás pode ser uma das causas de ciática.
\end{abstract}

received

February 18, 2017

accepted

April 7, 2017
DOI https://doi.org/

10.1055/s-0037-1603986.

ISSN 0103-5355.
Copyright $\odot 2017$ by Thieme Revinter

Publicações Ltda, Rio de Janeiro, Brazil

License terms

(c) (i) $\ominus$ () 


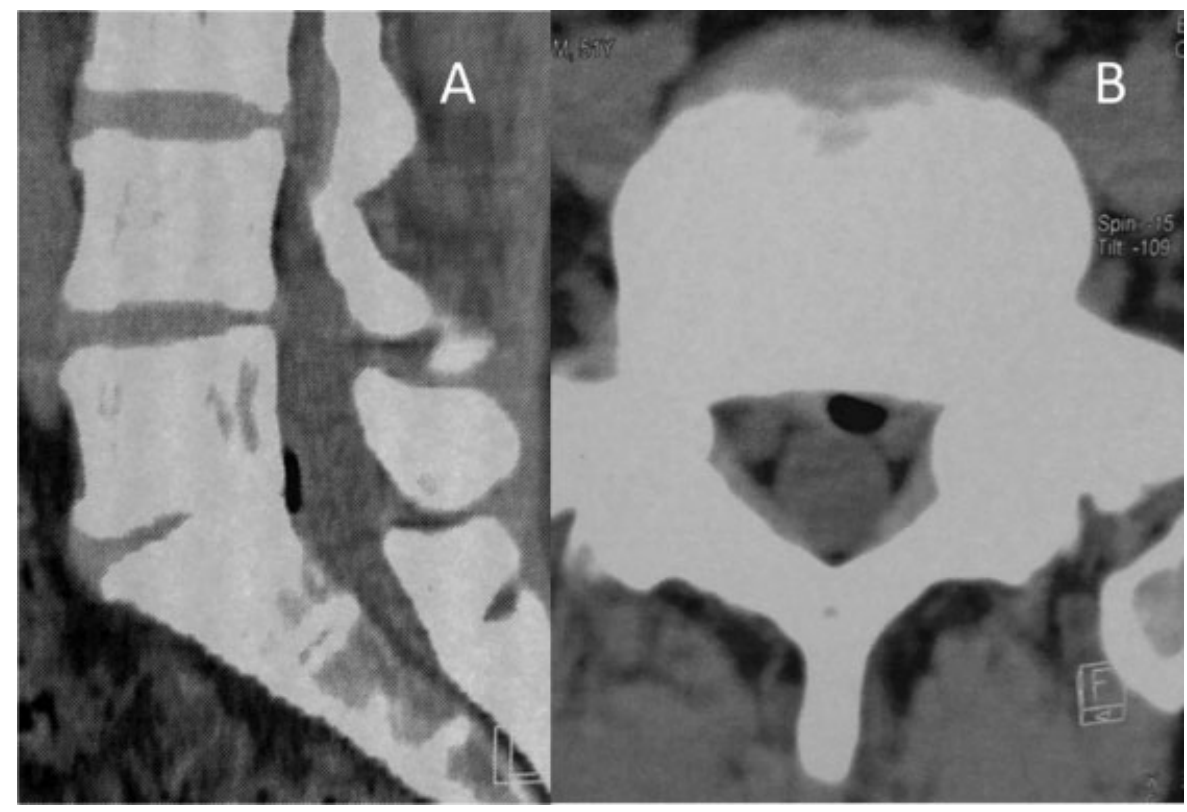

Fig. 1 Sagittal reformatted (Panel A) and axial reformatted (Panel B) computed tomography image of lumbosacral spine showing clearly a lateral disc herniation and gas pseudocyst with evidence of root compression.

\section{Introduction}

The most common causes of lumbar radiculopathy are intervertebral disc herniation and lumbar canal stenosis. ${ }^{1}$ Intraspinal extradural masses like disc cysts, perineural cysts, synovial cysts, and ganglion cysts are rare causes. ${ }^{1}$

Intraspinal gas has been reported in several situations, including craniocervical trauma, epidural anesthesia, spinal surgery, infection and tumors. ${ }^{2}$ First reported in 1980 by Gulati and Weinstein, ${ }^{3}$ an association between disk herniation and gas pseudocyst has rarely been reported ever since. We report a case of this unusual clinical presentation.

\section{Case Report}

A 49-year-old Moroccan man was admitted to our department presenting with sciatica for 10 days. The neurological examination objectified a moderate low back pain without neurological deficit. A lumbosacral spine computed tomography scan (-Fig. 1: Panel A and B) showed the presence of a degenerated disc hernia and an epidural gas collection with evidence of root compression. The patient refused surgery after improvement achieved under medical treatment.

\section{Discussion}

Gas in the intervertebral disk space is a relatively common radiologic finding, seen in $46 \%$ of cases on computed tomography examinations. ${ }^{4}$ However, the existence of gas within the spinal canal has been seen in only a few cases in the literature worldwide, ${ }^{5}$ and an epidural gas pseudocyst compressing a nerve root associated with a lateral disc herniation is also a rare clinical presentation.,7

This pathological association between the cyst and the hernia is probably due to the migration of gas pumped from the intervertebral space through a breaking point in the annulus fibrosis, involving its contiguity with the herniated disc. ${ }^{8}$

The vacuum phenomenon in the intervertebral disk space and gas accumulation in the epidural space can be better characterized with CT by its typical attenuation values. Also, associated findings include osteophytes of adjacent vertebral bodies and degeneration of discs; ${ }^{6}$ but magnetic resonance imaging is a good modality for evaluation of the intervertebral disc, the spinal cord and the nerve roots. ${ }^{9}$

Surgery is the preferred treatment in chronic encapsulated lesions that do not resolve with conservative management. ${ }^{10,11}$

\section{Conclusion}

Through this clinical case, we find that an association between a disc herniation and an epidural gas pseudocyst can be a cause of sciatica.

\section{References}

1 Jeong GK, Bendo JA. Lumbar intervertebral disc cyst as a cause of radiculopathy. Spine J 2003;3(03):242-246

2 Ilica AT, Kocaoglu M, Bulakbasi N, Kahraman S. Symptomatic epidural gas after open diskectomy: CT and MR imaging findings. AJNR Am J Neuroradiol 2006;27(05):998-999

3 Gulati AN, Weinstein ZR. Gas in the spinal canal in association with the lumbosacral vacuum phenomenon: CT findings. Neuroradiology 1980;20(04):191-192

4 Belfquih H, El Mostarchid B, Akhaddar A, gazzaz M, Boucetta M. Sciatica caused by lumbar epidural gas. Pan Afr Med J 2014;18:162

5 Lardé D, Mathieu D, Frija J, Gaston A, Vasile N. Spinal vacuum phenomenon: CT diagnosis and significance. J Comput Assist Tomogr 1982;6(04):671-676

6 Hidalgo-Ovejero AM, Martinez-Grande M, Garcia-Mata S; HIDALGO OVEJERO A.M. Disc herniation with gas. Spine 1994; 19(19):2210-2212 
7 Battal B, Bozlar U, Sanal H, Saglam M, Bulakbasi N, Ustunsoz B. Symptomatic epidural gas accumulation originating from vacuum phenomenon in the intervertebral disc: $\mathrm{CT}$ imaging findings. The Internet Journal of Radiology. 2008;10(01):1-4

8 Salpietro FM, Alafaci C, Collufio D, et al. Radicular compression by lumbar intraspinal epidural gas pseudocyst in association with lateral disc herniation. Role of the posterior longitudinal ligament. J Neurosurg Sci 2002;46(02):93-95, discussion 95
9 Giraud F, Fontana A, Mallet J, Fischer LP, Meunier PJ. Sciatica caused by epidural gas. Four case reports. Joint Bone Spine 2001; 68(05):434-437

10 Tamburrelli F, Leone A, Pitta L. A rare cause of lumbar radiculopathy: spinal gas collection. J Spinal Disord 2000;13(05):451-454

11 Demierre B, Ramadan A, Hauser H, Reverdin A, Rilliet B, Berney J. Radicular compression due to lumbar intraspinal gas pseudocyst: case report. Neurosurgery 1988;22(04):731-733 